Received: 19/02/2016

Revision: 29/06/2016

Accepted: 30/06/2016

\title{
Text-Selection for Teaching Reading to ESL Tertiary Students: A Study on Genre and Content Preferences
}

\author{
Razanawati Nordin \\ Doctor of Education (TESOL) Scholar, School of Educational Studies, Universiti Sains \\ Malaysia; Lecturer, University Teknologi MARA Kedah Branch, Malaysia, \\ razanawati@kedah.uitm.edu.my
}

Lin Siew Eng

Senior Lecturer, School of Educational Studies, University Sains Malaysia, selin@usm.my

Most learners studying English language feel that their educators use irrelevant, uninteresting, and culturally unfamiliar reading materials for teaching reading. As a result, most of them struggle to comprehend the English language texts used by the teachers. Therefore, the aim of this research is to investigate the genre and content preferences of ESL tertiary learners in UiTM Kedah, Malaysia. A two-part questionnaire was administered to 132 respondents aged 20 to 23 years old who are presently furthering their undergraduate studies in Accountancy, Administrative Science and Policy Studies, Business Management, Industrial Design, and Information Management. The results of the study show that these ESL tertiary learners prefer texts from the websites and blogs; and their preferred reading contents are dealing with Business Management, watching movies and listening to music. This article offers guidance to ESL teachers to select L2 reading texts based on the students' preferred genre and content.

Key Words: content preference, culturally unfamiliar, ESL tertiary learners, genre preference, reading text

\section{INTRODUCTION}

Reading is the most essential skill for all university learners. When a learner can read and comprehend English texts effectively, he/she has established himself/herself as an effective reader. When a learner has poor reading skills, he definitely has to make a great effort grasping and acquiring new knowledge throughout his academic years. In Malaysia, it is common to observe that ESL tertiary learners fail to grasp the basics of reading especially when reading the academic texts. It was reported that Malaysian university learners have problems in tackling their academic reading texts (Isarji \& Ainul, 2008; as cited in Rahim, 2013) because they are "unable to fully understand what 
they read, and fail to apply appropriate ideas from their readings to course-related tasks (Kuldip, 2001; as cited in Rahim, 2013). In another study, it has reported that tertiary learners in Malaysia have limited critical ability because of the didactic nature of the learning process (Ahmad, 2007; as cited in Kaur \& Sidhu, 2014). Furthermore, Malaysian tertiary learners lack conventions of academic writing, are weak at understanding long sentences or sentences with difficult words, and that have imposed limitations and barriers on students' comprehension abilities (Nambiar, 2007; as cited in Kaur \& Sidhu, 2014). In another study, many Malaysian tertiary learners struggle to locate information from a reading text and often do not engage critically or constructively to obtain meaning from text (Zaira, 2008; as cited in Kaur \& Sidhu, 2014). Other several researchers also conclude that Malaysian ESL learners are not able to operate autonomously when they engage with a range of academic reading tasks (Koo, Wong \& Kemboja, 2012; Kaur, Ganapathy \& Sidhu, 2012; Kaur, 2013, as cited in Kaur \& Sidhu, 2014). As a result, the students treat reading as a chore that is monotonous and not stimulating (Grabe, \& Stroller, 2002; as cited in Rahim, 2013). Therefore, what can English language educators do to inspire reading in the classroom?

\section{Background of the study}

UiTM Kedah is located at a nearby small town called Semeling at the northern state of Malaysia. It is a public university that offers diploma and degree programmes emphasizing on the study of social sciences. Accommodating 5,000 students per semester, this small campus only welcomes the Malay students who are from the below average income family background. Their family mostly resides at remote rural areas such as Yan, Sik, Jeniang, Guar, Tanjong Dawai and to name a few. Therefore, it is common to have students who have backgrounds such as fishery, rubber tapping, paddy planting, and other odd jobs.

As a state campus in Kedah, it has minimal control over the curriculum including the ESL courses, as the main campus makes the major decisions on the course syllabus, test specification, work scheme, lesson plans and academic calendar. The main campus delivers the curriculum to the state campuses, and later the lecturers all over the branches have to decide on which texts to include, for what purposes to use them, and what activities will be done to explore the texts and promote language development. Therefore, the lecturers and students in this campus rely heavily on textbooks as they control the content, methods, and procedures of learning. These students learn what is shown in the textbook, and the way the textbooks present the material is the way students learn it (Kitao \& Kitao, 1997). The main argument should be highlighted as how far these textbooks are able to capture the students' needs and interest. Are students able to stay stimulated and engaged?

The word 'interest' in relation to learning means an experiential state distinguished by attention, effortless, engagement, and feelings of pleasure (Green-Demers, Pelletier, Steward, and Gushue 1998; Silva, 2006, as cited in Wisniewska, 2013). Interest influences learners' choices of activities, intrinsic, motivation, and use of cognitive strategies (Albin, Benton, and Khramtsove 1996; as cited in Wisniewka, 2013). Therefore, interest is a strong motivational variable in one's life. It can engage learners' 
experience to their familiar objects, events, activities or ideas. Therefore, Hidi and Renninger (2006) sum up that interest is an important condition for learning, and educators can help learners to develop the interest. In fact, educators could make a significant contribution to the development of students' academic interest (Hidi \& Renninger, 2006).

In a previous study on reading interest, it claims that there is a positive relationship between reading interests and reading comprehension. When the interest is high, learners read resources that are above their proficiency levels. But, when the interest is low, learners often rate books as too hard even when they are below their reading levels (Spache \& Shnayer, 1967; as cited Al-Nafisah \& Al-Shorman, 2011). Without interest, students hesitate to read the text.

\section{STATEMENT OF PROBLEM}

In UiTM Kedah, the ESL reading courses emphasises the final product of reading. It focuses on the learner's ability to answer the questions posed at the end of the reading. Little attention is given in teaching learners to undergo several reading processes as they decode the text. When learners are trained to treat reading as question-regimented task, they see reading as a chore that is monotonous and not stimulating (Grabe \& Stroller, 2002; as cited in Puteri, 2013). This happens because the lecturers depend heavily on the prescribed textbooks and manuals.

Most English language textbook authors and publishers can not possibly know the needs of a particular audience in order to make crucial instructional decisions (Hedgcock \& Ferris, 2009). Some contents and arrangements of a textbook may not suit the interests, needs, or expectations of a particular cohort (Hedgecock \& Ferris, 2009). Moreover, textbooks are too inflexible to be used directly as instructional materials (Allwright, 1990; as cited in Kitao \& Kitao, 1997). Other than that, some reading selections, exercises, articles, and visual enhancements may be inauthentic, unappealing, or too tightly controlled for length and lexical complexity leading to boredom and low motivation on the part of learners (Hedgcock \& Ferris, 2009). Ultimately, learners opt for resistance towards the difficulty of the text (Hedgcock\& Ferris, 2009).

Therefore, to encourage the ESL tertiary learners to enjoy the reading course, the lecturers can bring supplementary L2 reading texts to the classroom. Most lecturers find that it as a complex task to select appropriate reading passages to teach (Arias, 2002). They find the text-selection task as tedious as they have to consider many issues. In the process, teachers could not find the appropriate text due to lack of suitable reading materials to facilitate ESL learners with different abilities to enhance their reading comprehensions (David \& Govindasmy, 2006; as cited in Javed, Lin, \& Mohammed Rashid, 2015).

\section{Objectives of the study}

The objectives of this study are as follow:

O1: To find out the preferred reading genre among ESL tertiary learners in UiTM Kedah for text-selection. 
O2: To find out preferred reading content among ESL tertiary learners in UiTM Kedah for text-selection.

\section{Research questions}

In this study, there are two research questions being designed to achieve the objective of the study.

RQ1: What are the genre preferences of the ESL tertiary learners in UiTM Kedah?

RQ2: What are the content preferences of the ESL tertiary learners in UiTM Kedah?

\section{REVIEW OF LITERATURE}

The schema theory is the key to the study. The researchers are also exploring on the learners' reading preferences on the text types and the content of the text. Since, previous studies only offer the guidelines to select texts to teachers, in this study it is aimed to explore the needs of the students.

\section{Using the Schema Theory as the Process of Text-Selection}

The researcher believes that schema theory plays an important influence in this study. The schema theory highlights that a text does not carry the meaning but the reader brings the information, knowledge, emotion, experience, and culture to the texts (Brown, 2001, p. 299). Therefore, when teachers select reading texts to teach based on students' interest, the teachers uses students' prior knowledge and experience to make students stay connected. As the learners stay connected to the text, they can pick up the new words and learn the language. The term "schema" itself was first used by Barlett (1932; as cited in Stott, 2001) as "an active organization of past reactions or experiences", later schema was introduced in reading by Rumelhalt (1980), Carrell (1981) and Hudson (1982) when discussing the important role of background knowledge in reading comprehension (Stott, 2001). Therefore, the text only provides directions for students but their interest can retrieve or construct meaning from their own previously acquired knowledge. Furthermore, the schema theory highlights that comprehending a text is an interactive process between the reader's background knowledge and the text. By doing so, students may able to achieve efficient comprehension by relating the textual material to their own knowledge.

\section{Capitalising on Learners' Preferences}

\section{Genre}

Genre by definition is text types. Educators may prefer college textbooks but learners show variation as to the types of text they prefer to read in the classroom. A variety of genre categories can be: academic articles and essays, novels, short stories, non-fiction (e.g. biographies, history, travel, and popular science), poetry, newspapers and newsmagazines, magazines, cook books, manuals, comic book, websites and blogs. In other words, educators can select from various genre to lure the learners to love reading. But does one know which genre is the most preferred by the learners? By doing this research, educators can get answer to the question which popular genres the learners feel at ease to learn $\mathrm{L} 2$ reading in the classroom. 


\section{Content}

Content is defined as subject matter. The researchers believe that the most important criterion in selecting reading materials for the learners is the suitability of the content, i.e. the reading texts "should interest the readers - preferably fascinate and delight them" (Nutal, 2000; as cited in Yee, Chong, \& Ng, 2012). Moreover, the reading materials must be a good fit for educators, learners and the curriculum which are important and appropriate to the particular context (Mieklye, 2005).

In this study, the researcher would like the teachers to analyse the students' preferred content. The teacher can bring in relevant texts which are related to student interests, which deal with situations or ideas which students perceive as meaningful and important to them (Hetherington, 1985). In another study, the most significant factors in the reading selection process are related to the students: the students' level, interests, needs, and background knowledge. Other factors are related to the text itself: content, relevance and authenticity (Jimenez, 2007). By introducing relevant reading materials for the learners, it creates an interest that will assist learners in acquiring linguistics competence and increase their confidence levels (Meurant, 2010).

Educators may have a particular content to be introduced in the classroom, but learners may enjoy reading on a different subject matter such as online shopping, while others may enjoy reading materials about food, social media, marriage or families. The list of content preference can be long and growing. At times, the list can keep changing. Therefore, educators may require an extensive investigation to learn what learners want to read, and the information gathered later can be meaningful and valuable in the classroom.

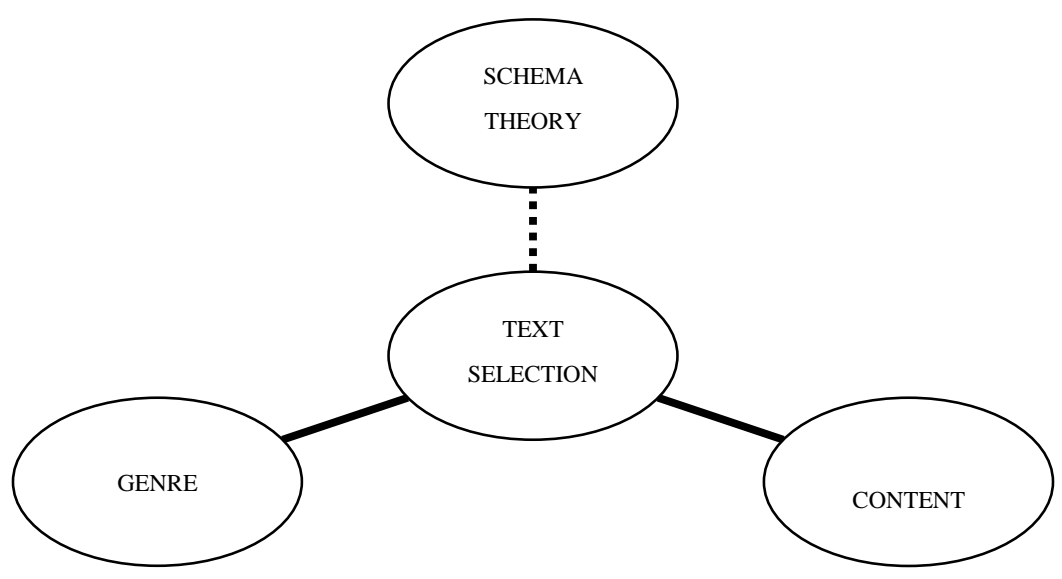

Figure 1

Model of the Study 


\section{METHOD}

In this study, the researchers have opted for one testing instrument - a survey questionnaire.

\section{Respondents}

The population of the study consisted of 132 Malay learners aged between 21 to 23 years old at Universiti Teknologi MARA (UiTM) Kedah, Northern Malaysia. 21.2 percent of the students were male and 78.8 percent of them were female who are studying degree in semester four and five. They are being selected from five different faculties, which are Faculty of Accounting, Faculty of Business Administration, Faculty of Arts and Design, Faculty of Information Management, and lastly Faculty of Administrative Science and Policy Studies. Being the tertiary students, they have an exposure of English language for 20 to 22 years since primary school.

\section{Questionnaire}

The respondents were asked to complete the questionnaire in their classroom. The questionnaire consisting of seven sections was taken from a reference book entitled Teaching Readers of English Students, Texts, and Contexts (Hegdcock \& Ferris, 2009). It was constructed by several teachers based on previous studies (Hedgcock \& Ferris, 2009). The researchers chose this particular questionnaire because it corresponds with the researchers' purposes; and the test is designed solely for tertiary learners. The usability of the questionnaire was tested through a pilot study of 28 students from semester five. Later, the questionnaire was given to three senior lecturers to elicit their views as to the accuracy and appropriateness of the instrument. Finally, the researchers limited the sections from seven to three.

The first section aimed at collecting the background information about the respondents such as name, number of years of studying English, faculty and degree programmes and their favourite pastimes and interests.

The second section aimed at collecting learners' genre preferences towards reading L2. The third section aimed at investigating learners' content preferences towards reading L2. It was divided into two sub-sections - preferences of studies for future career; and preferences of issues, pastimes or interest. Once the questionnaires are collected, the data is processed using the SPSS version 22.

\section{FINDINGS}

The first research question investigated the genre preferences among the ESL tertiary learners in UiTM Kedah. By understanding their genre preferences, it can offer assistance to teachers for selecting reading materials in the classroom. In Table 1, it shows the general outcome of the questionnaire. The relevant finding is in Table 2 which highlights the item - 'I read this kind text often'. Therefore, it can be concluded that the students preferred reading L2 from the websites and blogs often and amazingly the finding is similar to the pilot study which was conducted to 28 respondents. 
It seems that 55.3 percent of the students prefer websites whereas 43.9 percent of them prefer blogs as their preferred L2 reading genre. It is not a surprise as this new generation is fully exposed to technology, digital media and internet. They are exposed to the online reading materials since primary schools. Therefore, educators are highly recommended to bring in supplementary L2 reading materials from the websites and blogs. The learners feel that websites and blogs are current and relevant to their experience compared to poetry. Looking at the current Malaysian school curriculum, poetry is not highly emphasised in the classroom and it made the text as the least preferred genre.

Table 1

Genre Preferences

\begin{tabular}{|c|c|c|c|c|}
\hline $\begin{array}{l}\text { How often do you read the following kinds of } \\
\text { texts (genres) in English? }\end{array}$ & $\begin{array}{l}\text { Often } \\
(\%)\end{array}$ & $\begin{array}{l}\text { Sometimes } \\
(\%)\end{array}$ & $\begin{array}{l}\text { Never } \\
(\%)\end{array}$ & $\begin{array}{l}\text { Don't Know } \\
(\%)\end{array}$ \\
\hline 1. $\quad$ College textbooks & 27.3 & 66.7 & 5.3 & 0.8 \\
\hline Academic articles and essays & 22.7 & 74.2 & 2.3 & 0.8 \\
\hline Fiction (e.g. novels, short stories) & 34.8 & 53.8 & 8.3 & 2.3 \\
\hline $\begin{array}{l}\text { 4. Non-fiction (e.g. biographies, history, } \\
\text { travel, popular science) }\end{array}$ & 18.9 & 61.4 & 16.7 & 3.0 \\
\hline 5. Poetry & 3.8 & 46.2 & 37.1 & 10.6 \\
\hline Newspapers and newsmagazines & 33.3 & 59.8 & 5.3 & 0.8 \\
\hline Magazines (other than newsmagazines) & 26.5 & 65.2 & 4.5 & 0.8 \\
\hline $\begin{array}{l}\text { 8. Technical and practical texts (e.g. Cook } \\
\text { books, Manuals) }\end{array}$ & 18.2 & 63.6 & 16.7 & 1.5 \\
\hline 9. Comic book & 29.5 & 47.0 & 18.9 & 3.8 \\
\hline 10. Websites & 55.3 & 38.6 & 5.3 & 0.8 \\
\hline 11. Blogs & 43.9 & 44.7 & 10.6 & 0.8 \\
\hline
\end{tabular}

Next, the second research question aims at finding the content preferences among ESL tertiary learners in UiTM Kedah. After selecting the genre, the educators will be able to choose appropriate content for their learners.

In Table 2, it shows the finding for content preferences in general. Similar to the pilot study, when it comes to topics related to studies and future career, the students opt for Business Management with 37.9 percent of them read the content often (Refer to Table 3). In UiTM Kedah, the tertiary students are trained to get involved in the world of entrepreneurship. They are exposed to Business courses and clubs as to prepare themselves to start their own business and be independent after graduating. Therefore, majority of them prefer to read up on that subject matter.

Other than that, Language Studies are also the second preferred content among the respondents. This is because the students are exposed to Language Studies in the first semester. They are encouraged to take third language as well. Therefore the educators are encouraged to select L2 texts on Business Management and Language Studies. The content of the L2 texts may cover topics on how to start an online business, how to start business via social media or how to learn new language. Educators should be aware that texts on Law and Computer Science are on the least preferred topics among these young 
adult learners as only 9.8 percent and 3 percent read the topic often. These contents may discourage the learners to comprehend the texts.

Table 2

Content Preferences - Topics related to studies and future career

\begin{tabular}{|c|c|c|c|c|}
\hline $\begin{array}{l}\text { How often do you read the following topics in } \\
\text { English? }\end{array}$ & \multicolumn{2}{|c|}{ Often Sometimes } & \multicolumn{2}{|c|}{$\begin{array}{l}\text { Never Don't Know } \\
(\%)(\%)\end{array}$} \\
\hline 1. Business Management & 37.9 & 43.2 & 13.6 & 5.3 \\
\hline Industrial Design & 9.8 & 28 & 47.7 & 12.9 \\
\hline 3. Information Management & 2 & 41.7 & 25.8 & 6.8 \\
\hline 4. $\quad$ Administrative Science and Policy Studies & 10.6 & 22 & 51.5 & 14.4 \\
\hline 5. $\quad$ Accountancy & 15.9 & 38.6 & 31.8 & 12.9 \\
\hline 6. Law & 9.8 & 40.9 & 35.6 & 12.9 \\
\hline 7. Computer Science & 3 & 32.6 & 43.9 & 17.4 \\
\hline 8. Mathematics & 18.9 & 50.8 & 24.2 & 5.3 \\
\hline 9. Contemporary Islamic Studies & 17.4 & 54.5 & 19.7 & 5.3 \\
\hline 10. Language Studies (English, Mandarin, Arabic, etc) & 35.6 & 52.3 & 11.4 & 0.8 \\
\hline 11. Finance & 12.9 & 45.5 & 31.1 & 10.6 \\
\hline 12. Economy & 13.6 & 47 & 31.1 & 7.6 \\
\hline
\end{tabular}

The result in Table 3 below shows the content preferences among tertiary learners focusing on favourite issues and pastimes in general. It highlights that 72.7 percent of the learners' preferred contents which are related to movies, and 70.5 percent of the learners preferred content related to music. Even in the pilot study, the results are similar whereby the movies and music are most preferred. Educators should consider subject matters on how to make a movie, how to write a movie scripts, how to shoot horror movies, or perhaps on how to write a song.

Besides reading about movies and music, the learners preferred reading content on vacation, shopping, food, and hobbies. The least favourite reading content would be on health, people and biography, relationships, and sports.

Table 3

Content Preferences - Topics related to issues or pastimes

\begin{tabular}{lllll}
\hline $\begin{array}{l}\text { How often do you read the following topics } \\
\text { in English? }\end{array}$ & $\begin{array}{l}\text { Often } \\
(\%)\end{array}$ & $\begin{array}{l}\text { Sometimes } \\
(\%)\end{array}$ & $\begin{array}{l}\text { Never } \\
(\%)\end{array}$ & $\begin{array}{l}\text { Don't Know } \\
(\%)\end{array}$ \\
\hline 1. Movies & 72.7 & 26.5 & 0.8 & 0 \\
\hline 2. Music & 70.5 & 28 & 1.5 & 0 \\
\hline 3. Sports & 25.8 & 50.8 & 21.2 & 1.5 \\
\hline 4. Vacation \& Travelling & 48.5 & 37.9 & 11.4 & 1.5 \\
\hline 5. Hobbies (Indoor or outdoor activities) & 43.9 & 46.2 & 9.8 & 0 \\
\hline 6. Shopping & 46.2 & 41.7 & 9.8 & 1.5 \\
\hline 7. People \& Biography & 16.7 & 60.6 & 19.7 & 3.0 \\
\hline 8. Technology & 32.6 & 55.3 & 11.4 & 0.8 \\
\hline 9. Fashion & 39.4 & 47 & 12.1 & 1.5 \\
\hline 10. Food & 44.7 & 51.5 & 3 & 0.8 \\
\hline 11. Health & 3.1 & 62.1 & 5.3 & 1.5 \\
\hline 12. Relationships & 22.7 & 63.6 & 12.1 & 1.5 \\
\hline
\end{tabular}




\section{CONCLUSION}

There are many other aspects to consider when it comes to text selection in L2 reading classroom. Research can tell us which kind of practices are effective in general, but eventually only individual educators can determine what is the most effective one for them and the particular group of students they are teaching at the moment (Irujo, 2007). It is the educator who plays the key role to facilitate reading and making the learners as effective readers.

The main focus of this study was analysing the learners' preferences towards reading genre and content. By understanding the genre and content in a classroom, the educators can set it as a benchmark to customize their supplementary reading materials and never make the mistake of turning the reading class into a boring classroom. Boring classroom produces boring learners. Boring learners make dull readers.

Thus, educators must make reading materials relevant to the ESL tertiary learners. Once the learners find it relevant, they feel motivated to explore their own needs. As a result, they can become more engaging towards learning to read. Not only that, the educator is able to enhance their teaching materials for reading. In short, the findings of this research assists educators to be creative to select and modify the texts based on their learners' background, needs, and level of proficiency. Educators can take these as the simple steps to select the L2 texts by:

1. Selecting the reading text matches the theme and outcomes for the curriculum,

2. Choosing reading materials that are appropriate for age of the students' and relevant for the audience,

3. Adapting the text to fit the learners' proficiency, content familiarity, interests and genre. With all of the above as considerations, educators can make reading as a fun learning experience.

\section{REFERENCES}

Al-Nafisah, K., \& Al-Shorman, R.A. (2011). Saudi EFL students' reading interests. Journal of King Saud University - Language and Translation. 23.

Arias, I.J. (2007). Selecting reading materials wisely. LETRAS. 41. 131-147. Retrieved from www.revitas.una.ac.cr/index.php/letras/article/viewFile/648/583

Brown, H.D. (2001). Teaching by principles: An interactive approach to language pedagogy - Second Edition. New York: Pearson.

Day, R.D. (1994). Selecting a passage for the EFL reading class. 32 (1). Retrieved from http://dosfan.lib.uic.edu/usia/USIA/forum/vols/vol32/no1/p20.htm

Hedgcock, J.S., \& Ferris, D.R. (2009). Teaching readers of English students. Routledge: New York.

Heringthon, A. (1985). Assessing the suitability of reading materials for ESL Students. TESL Canada Journal , 37 - 50. 
Hidi, K. \& Renninger, A. (2006). The Four-Phase Model of Interest Development. Educational Psychologoist. 41(2), 111-127.

Irujo, S. (2007). What does research tell us about teaching reading English language learners?. ELL Outlook . Retrieved from www.usc.edu/.../543IrujoResearchRead.

Jacobs, G.M. (2014). Selecting extensive reading materials. Beyond Words. 2(1). Retrieved from http://journal.wima.ac.id/index.php/BW/article/view/513

Javed, M., Lin, S.E., \& Mohamed, A.R. (2015). Developing reading comprehension modules to facilitate reading comprehension among Malaysian secondary school ESL students. International Journal of Instruction. 8(2).

Lee, S., \& Pulido, D. (2016). The impact of topic interest, L2 proficiency, and gender on EFL incidental vocabulary acquisition through reading. Language Teaching Research, 1362168816637381.

Kaur, S. \& Sidhu, G.K. (2014). Evaluating the critical literacy practices of tertiary students.

Kitao, K. \& Kitao, S.K. (1997). Selecting and developing teaching/learning Materials. The Internet TESL Journal. 4(4). Retrieved from http://iteslj.org/

Lima, C. (2010). Selecting Literary Texts for Language Learning. Journal of NELTA. 15(1). 110-113.

Megat Abdul Rahim, P. R. (2013). Pedagogy for meeting the challenges of tackling reading amongst university students.Procedia - Social and Behavioral Sciences 72-79.

Meurant, R.C. (2010). EFL/ESL Textbook selection in Korea and East Asia - Relevant Issues and Literature Review. Springer - Verlag Berlin Heidelberg.p 89-102.

Miekley, J. (2005). ESL textbook evaluation checklist.The Reading Matrix.Vol. 5, No.2.

Mukundan, J., Zarifi, A., \& Kalajahi, S. A. R. (2016). Developing Reading Materials for ESL Learners. In Issues in Materials Development (pp. 65-73). SensePublishers.

Pehlivan, A. Serin, O., \& Serin, N.B. (2010). Determining reading interests and habits of candidate teachers (TRNC sample). Procedia Social and Behavioral Sciences. 9. Retrieved from www.sciencedirectcom.

Schullstrom, F. (1996). Guidelines for Selection of Materials in English Language Arts Programs. Retrieved from 
Stott, N. (2001). Helping Esl Students Become Better Readers: Schema Theory Applications And Limitations. The Internet Tesl Journal, 7(11). Retrieved From http://Iteslj.Org/Articles/Stott-Schema

Thomas, C. (2014). Meeting Efl Learners Halfway By Using Locally Relevant Authentic Materials. English Teaching Forum. 15-23.

Wang, W.C., Lin, C.H., \& Lee, C.C. (2011). Thinking of the textbook in the ESL/EFL classroom. Canadian Center of Science and Education. 4(2). Retrieved from www.ccsenet.org/elt

Wiśniewska, D. (2013). Interest and interest-enhancing strategies of adolescent EFL learners. ELT journal, 67(2), 210-219.

Yee, C.L., Chong, S. T., \& Ng, Y.J. (2012). Evaluating the ESL reading texts for intermediate learners of English from the perspective of students. Global Journal of Human Social Science. 12(7).

Yusoff, Z.S.H. (2004). Cultural familiarity in literary texts: Consideration for textselection. Retrieved from www.umpir.ump.edu.my/926/1/11_zailinmi_cultural.pdf 


\section{Turkish Abstract İngilizceyi İkinci Dil Olarak Kullanan (ESL) Öğrenciler İçin Öğretimde Metin Seçimi: Tür ve İçerik Tercihleriyle İlgili Bir Araştırma}

İngilizce dilini araştıranların çoğu, eğitmclerinin ingilizce okumayı öğretirken ilgisiz, ilginç olmayan ve kültürel açıdan yabancı okuma materyallerini kullandıklarını düşünür. Sonuç olarak öğretmenler tarafindan kullanılan bu ingilizce metinleri anlamaya çalışırlar. Bu yüzden bu araştırmanın amacı Kedah Malezya'daki MARA Teknoloji Üniversitesi'nde İngilizceyi ikinci dil olarak kullanan (ESL) öğrencilerin için tür ve içerik tercihlerini incelemektir. İki bölümden oluşan anket halen üniversitede lisans öğrenimine devam eden, yaşları 20 ile 23 arasında değişen muhasebe, Siyasi Bilimler, İş Yönetimi, Endüstriyel Tasarım ve Bilgi Yönetimi bölümlerinde okuyan öğrenciler tarafından doldurulmuştur. Çalışmanın sonuçları İngilizceyi ikinci bir dil olarak öğrenen öğrencilerin internet sitelerinden ve kişisel günlüklerden alınan metinleri tercih ettiği ve bu metinlerin içeriğinin iş yönetimi, izlenen filmler ve dinlenen müziklerden oluştuğunu göstermiştir. Bu makale ESL öğretmenlerine seçmeleri için öğrencilerin tür ve içerik olarak tercihlerine dayanan okuma metinleri sunmuştur.

Anahtar Kelimeler: içerik tercihleri, kültürel açıdan yabancı, ingilizceyi ikinci bir dil olarak öğrenen öğrenciler, tür tercihleri, okuma metinleri

\section{French Abstract \\ Sélection de texte pour Enseigner Lecture à Étudiants Tertiaires ESL : une Étude sur Genre et Préférences de Contenu}

La plupart des apprenants étudiant la langue anglaise estiment que leur utilisation d'éducateurs des matériels de lecture sans rapport, non intéressants et culturellement peu familiers pour enseigner la lecture. En conséquence, la majeure partie d'entre eux lutte pour comprendre les textes de langue anglaise utilisés par les professeurs. Donc, le but de cette recherche est d'examiner le genre et les préférences contentes(de contenu) d'apprenants tertiaires ESL dans UiTM Kedah, la Malaisie. Un questionnaire en deux parties a été administré à 132 défendeurs (personnes interrogées) a vieilli 20 à 23 ans qui favorisent actuellement leurs études de premier et second cycle dans la Comptabilité, la Science Administrative et des Études de Politique, la Gestion d'entreprise, le Design industriel et la Gestion de l'information. Les résultats de l'étude montrent que ces apprenants tertiaires ESL préfèrent des textes des sites Web et des blogs; et leur contenu de lecture préféré a affaire la Gestion d'entreprise, observant des films et écoutant la musique. Cet article offre des conseils aux professeurs ESL pour choisir L2 lisant des textes basés sur le genre préféré des étudiants et le contenu.

Mots Clés: content de préférence, culturellement peu familière, ESL des apprenants tertiaires, la préférence de genre, lisant le texte 


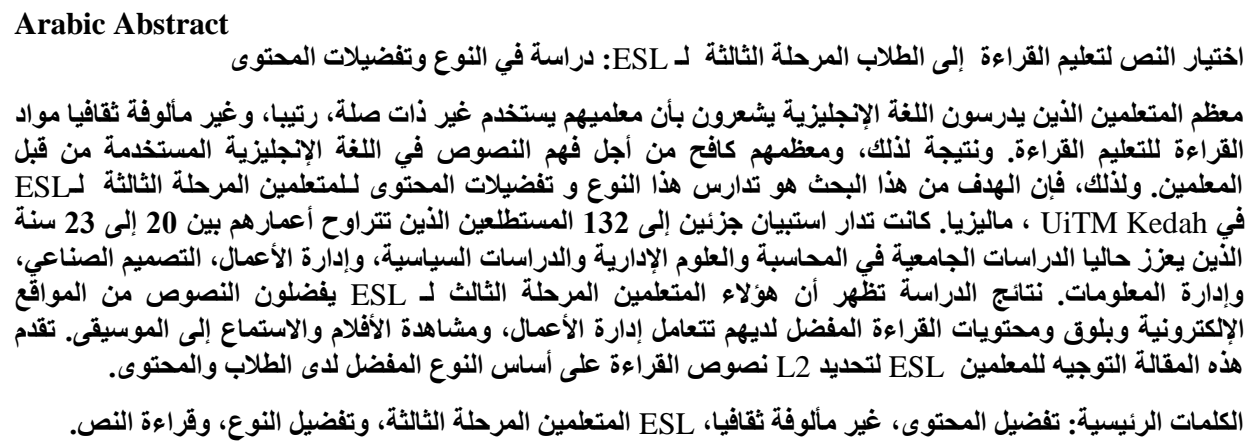

\section{German Abstract}

Text-Auswahl für das Lehren Lesen zu EZS Tertiäre Studenten: Eine Studie über Genre und Inhalt Präferenzen

Die meisten Lernenden, die englische Sprache studieren, fühlen, dass ihre Erzieher irrelevante, uninteressante und kulturell nicht vertraute Lesestoffe zum Lehren des Lesens verwenden. Infolgedessen kämpfen die meisten von ihnen, um die englischen Sprachtexte zu verstehen, die von den Lehrern benutzt werden. Ziel dieser Forschung ist es daher, die genetischen und inhaltlichen Vorlieben von ESL-Tertiärlern in UiTM Kedah, Malaysia, zu untersuchen. Ein zweiteiliger Fragebogen wurde an 132 Befragte im Alter von 20 bis 23 Jahren vergeben, die derzeit ihre Bachelor-Studien in Buchhaltung, Verwaltungswissenschaften und Politikwissenschaften, Betriebswirtschaftslehre, Industriedesign und Informationsmanagement fördern. Die Ergebnisse der Studie zeigen, dass diese EZS tertiären Lernenden Texte von den Websites und Blogs bevorzugen; Und ihre bevorzugten Leseinhalte sind Business-Management, Filme und Musik hören. Dieser Artikel bietet Leitlinien für ESL Lehrer, um S2 Lesung Texte auf der Grundlage der Schüler bevorzugte Genre und Inhalt zu wählen.

Schlüsselwörter: inhaltliche präferenz, kulturell nicht vertraut, ESL tertiäre lernende, präferenzen, lesen von text

\section{Malaysian Abstract}

Teks-Pemilihan Pengajaran Bacaan untuk ESL Pelajar Pengajian Tinggi: Satu Kajian Gaya Penulisan dan Keutamaan kandungan

Kebanyakan pelajar yang belajar bahasa Inggeris merasakan bahawa pendidik mereka menggunakan bahan bacaan yang tidak relevan, tidak menarik, dan tidak biasa dengan budaya mereka untuk pengajaran. Akibatnya, sebahagian besar daripada mereka berjuang untuk 
memahami teks bahasa Inggeris yang digunakan oleh guru-guru. Oleh itu, tujuan kajian ini adalah untuk menyiasat gaya penulisan dan kandungan citarasa pelajar pengajian tinggi ESL di UiTM Kedah, Malaysia. Terdapat dua bahagian soal selidik telah diedarkan kepada 132 responden yang berumur 20 hingga 23 tahun yang kini melanjutkan pengajian ijazah pertama dalam bidang Perakaunan, Sains Pentadbiran dan Pengajian Polisi, Pengurusan Perniagaan, Reka Bentuk Perindustrian, dan Pengurusan Maklumat. Hasil kajian menunjukkan bahawa pelajar ESL di institusi pengajian tinggi lebih suka teks dari laman web dan blog; dan kandungan bacaan pilihan mereka adalah berkaitan berurusan dengan Pengurusan Perniagaan, menonton filem dan mendengar muzik. Artikel ini memberi panduan kepada guru-guru ESL untuk memilih teks bacaan L2 berdasarkan gaya penulisan dan kandungan pilihan pelajar.

Kata Kunci: keutamaan kandungan, yang tidak dikenali budaya, ESL pelajar pengajian tinggi, gaya penulisan, teks bacaan

\section{Russian Abstract \\ Text-Отбор для Обучения Чтению CESL (Английский как Второй Язык): Исследование по Жанру и Контенту Предпочтения}

Большинство учеников, изучающих английский язык считают что их преподаватели используют неуместные, неинтересные, и чуткие по культуре материалы для обучения чтению. В результате, большинство из них борется чтобы осмыслить тексты на английском языке, используемые преподавателями. Следовательно, целью данного исследования является расследование жанра и содержания предпочтения английского языка в качестве второго языка (ESL) учащихся в UITM Кедах, Малайзия. Вопросник из двух частей вели 132 респондента в возрасте от 20 до 23 лет, которые в настоящее время учатся Бухгалтерскому учету, Административным Науким и Исследованим в Области Политики, Управления Бизнесом, Промышленный Дизайн, и Управление Информацией. Результаты исследования показывают, что для изучение английского языка в качестве второго языка (ESL) учащихся предпочитают тексты с сайтов и блогов; предпочтительнее чтение имеющее дело с Бизнес-Менеджментом, смотреть фильмы и слушать музыку. Данная статья предлагает наведение учителей английского языка в качестве второго языка (ESL) выбирать чтение L2 на основе текстов предпочитаемого жанра и содержания для студентов.

Ключевые Слова: контент предпочтения, в культурном отношении незнакомый, ESL учащиеся, жанровые предпочтения, чтение текстов 